\title{
In Favor of Rule-Based Monetization of Public Debt
}

\author{
Matthias Weber*
}

29 May 2020

Note: This piece appeared originally in German on 27 June 2018 in Ökonomenstimme (link).

\begin{abstract}
The expansive monetary policy conducted by the ECB in the past few years involves risks. However, the typical criticisms of the ECB are unjustified. The euro area would even be well advised to provide the ECB with rule-based monetization of public debt as additional policy instrument.
\end{abstract}

The monetization of public debt is explicitly prohibited in the Maastricht Treaty. The European Central Bank (ECB) is not allowed to buy government bonds (directly) from the member states of the monetary union. This ban on monetary financing of governments is considered irrefutable by many and is sometimes seen as a necessary precondition for good monetary policy. Most of the discussions in German-speaking countries about the ECB's expansionary measures in recent years took place against this background. However, the real problem is the opposite: the ECB does not have too much but too little leeway to fulfill its mandate.

Completely unregulated debt monetization, with the ECB sending governments money at will, would certainly be problematic. But what if the ECB (or the national central banks in the Eurosystem) were only allowed to monetize public debt under certain rules in order to better fulfill the mandate of price stability? This question is particularly relevant since the instruments currently available to the ECB (in particular quantitative easing) have some disadvantages and, despite their application, the inflation target has not been met for a long period of time.

That the ECB has started to reduce the volume of monthly security purchases is not enough for many observers - especially in Germany. Some advocate a faster exit from the extremely expansionary monetary policy. However, the macroeconomic data of the past few years make clear why the ECB went to the limits of its current mandate: consumer prices in the euro area rose significantly less than the desired 2 percent per year between 2013 and 2017 - thus, the ECB has not achieved its inflation target despite its extremely expansionary monetary policy. At the same time, the unemployment rate in the euro area has remained above 10 percent for more than six years. The social costs of the financial crisis were and are thus considerable. Too low inflation and high unemployment show that the combination of the ECB's monetary policy and the fiscal austerity policies in place in large parts of the euro area was insufficient. The ECB can hardly be blamed for this. Rather, its policies reflect the attempt to achieve the inflation target with all available means. For citizens and governments, it is essential that the expansionary measures contributed to combating unemployment and to stabilizing government budgets, but strictly speaking it is of secondary importance for the ECB.

\footnotetext{
* Currently: School of Finance, University of St. Gallen. At the time of the original German contribution: Bank of Lithuania and Vilnius University. The views in this article are those of the author and not necessarily those of the mentioned institutions. Special thanks go to Johannes Vatter. Email: matthias.weber@unisg.ch.
} 
The ECB used the means at its disposal to pursue its goal of price stability, but these means were not sufficient. After the zero lower bound was reached, the ECB tried other means. But also the controversial quantitative easing, which is the massive purchase of government bonds and other securities on the secondary market, has so far only had limited effects. While quantitative easing may have prevented deflation, the spent trillions were insufficient to achieve the moderate inflation target of about two percent.

\section{The side effects of current ECB policy}

In addition to the limited effectiveness of the ECB's monetary policy instruments, the current measures have a number of unpleasant side effects. The persistent low interest rate phase puts pension funds and insurance companies in a very difficult situation. Together with quantitative easing, this has considerable distributional consequences. In particular, there has been an increase in the concentration of wealth due to the ECB polices. While the poorer half of the population who does not own real estate or stocks experienced a stagnation of the value of their assets, the wealth of the richest 20 percent, which largely consists of real estate and stocks, has grown considerably.

Nevertheless, poorer people would not be better off without the ECB's easing measures, despite the associated greater wealth inequality. Expansionary monetary policy ensured that the labor markets in the euro area did not develop any worse, which benefited above all low-wage earners and people in precarious employment. However, rule-based monetization of public debt would have been a better alternative to the ECB's asset purchase programs. The effects of outright monetary financing on the economy, in particular unemployment and inflation, are more direct, so that the inflation target could have been reached more quickly. At the same time, the negative distributional side effects would have been significantly lower. Monetary financing is more effective than quantitative easing, because the effects of quantitative easing on labor markets and prices depend on those who sell the bonds putting the money they receive into circulation. Accordingly, that monetary government financing works better requires that the governments use the additional funds. The heads of state of the euro area could certainly agree on that. These additional funds from the ECB would be useful for all euro area countries. In Germany, they could be used to make urgently needed investments in infrastructure and education.

The combination of inflation below the target, high unemployment, and high public debt represents a situation in which the possibility of monetary government financing is advantageous, at least until the 2 percent inflation target is reached again. If the instrument is only available as long as the inflation target is undershot, the main concern of an uncontrolled devaluation of money would be unjustified. The ECB would maintain its independence and mandate of price stability. If inflation approaches its target, the ECB would have to stop monetizing public debt and could - as usually - react with interest rate increases. Inflation that is too high is much easier for the ECB to control (through its interest rate decisions) than inflation that is too low.

That monetary financing can easily lead to inflation in countries where the central bank is under the direct control of the government is of little relevance. In those countries, the government makes it impossible for the central bank to successfully fight inflation. However, this situation cannot arise in the euro area, as no national government has the possibility to curtail the independence of the ECB. Certainly, some governments might try to pressure the ECB to expand monetary financing. But the ECB is already exposed to public pressure today and yet a violation of its mandate cannot be observed. 


\section{Risks and implementation}

Wouldn't this form of monetary financing lead to a redistribution between the euro area countries? To prevent this, another rule would be needed. This rule would be that only all countries can be supported simultaneously, with financing proportional to their (economic) size, for example according to the ECB's capital key (which is already used for quantitative easing). This would keep the problem of redistribution between different euro countries under control and make the instrument also attractive for the north of the euro area.

There are various options for the technical details of monetary financing. One possibility would be that the national central banks would buy government bonds without interest and with long (or even infinite) time to maturity directly from the countries at face value - up to the limit set by the ECB and proportional to the capital key. The financial flows could be documented as liabilities of the countries and claims by the central banks.

It remains to be seen whether such rule-based monetary financing would still be appropriate at the present stage of the crisis. Economic growth in the euro area may be so stable this year that the ECB can reverse its bond purchase program and that prices will soon grow at a rate of close to two percent. If the recovery turns into a real boom, interest rates could then be raised to a level significantly above zero in the following years. However, such a development is by no means certain. Regardless of whether rule-based monetization of public debt would be appropriate at this moment, this instrument should now be considered to be prepared for the next crisis. 